\title{
Perubahan Organisasi Puskesmas dan Peran Akuntansi dalam Perspektif Teori Institusional
}

\author{
Novitasari Ayuningtyas \\ Sri Pujiningsih \\ Universitas Negeri Malang \\ Jalan Semarang 5, Malang, Indonesia, 65145 \\ novitasariayuningtyas@yahoo.co.id
}

\begin{abstract}
This study aims to find the significance of the actor on the change of Puskesmas (community health centre) into BLUD (regional public service agency) in the perspective of Institutional Theory and accounting role. This research uses qualitative method with phenomenological approach and interpretive paradigm. The data analysis stage is started from data collection through interview and documentation, reduction, presentation, and conclusion or verification. The results of this study show that the significance of actor of Puskesmas into BLUD from Coercive Isomorphism dimension in Institutional Theory perspective of is caused by the dominance of 100 Working Days Regulation and Program in the Government of Malang District. Besides, in terms of Mimetic Isomorphism dimension, there is a form of private model. Then, in Normative Isomorphism dimension, there were professional actors outside the organization adopting a certain concept related to PPK-BLUD (financial management system in regional public service agency). Meanwhile, if it was examined from the accounting role-7-particularly in Management Accounting-it intended to explore the Five-Years Annual Business Strategies and Budget Plans. In addition to this point, the internal control of medical supplies is identified from the perspective of Accounting Information System. Furthermore, in the aspect of Financial Accounting, it merely undertook SIMDA (regional management information system) without understanding the government accounting standards (SAP) and accrual accounting concept.
\end{abstract}

Keywords: Accounting Role, BLUD, Institutional Theory, Organizational Change

\begin{abstract}
Abstrak
Tujuan dari penelitian ini adalah untuk menemukan signifikansi aktor atas perubahan Puskesmas menjadi BLUD dalam perspektif Teori Institusional dan peran akuntansi. Penelitian ini menggunakan metode kualitatif dengan pendekatan fenomenologi dan paradigma interpretif. Tahapan analisis data dimulai dari pengumpulan data melalui wawancara dan dokumentasi, reduksi data, presentasi, dan penyimpulan atau verifikasi. Hasil penelitian menunjukkan bahwa signifikansi aktor pada perubahan Puskesmas menjadi BLUD dari dimensi Coercive Isomorphism dalam perspektif Teori Institusional disebabkan oleh dominasi dari Regulasi dan Program 100 Hari Kerja Pemerintah Kabupaten Malang. Disamping itu, dalam bentuk dimensi Mimetic Isomorphism, ditemukan adanya model swasta. Selanjutnya, dalam dimensi Normative Isomorphism, terdapat aktor-aktor profesional diluar organisasi yang mengadopsi konsep-konsep terkait PPK-BLUD. Sementara itu, jika diuji dari peran akuntansi-khususnya pada Akuntansi Manajemenpemaknaan aktor dimaksudkan untuk mengenal Rencana Strategis Bisnis Lima Tahunan dan Rencana Bisnis Anggaran (RBA) Tahunan. Selain itu, pengendalian internal untuk persediaan obat-obatan diidentifikasi dari perspektif Sistem Informasi Akuntansi. Lebih lanjut, dalam aspek Akuntansi Keuangan adalah sekedar menjalankan SIMDA tanpa memahami SAP dan konsep Akuntansi Akrual.
\end{abstract}

Kata Kunci: Peran Akuntansi, BLUD, Teori Institusional, Perubahan Organisasi

\section{PENDAHULUAN}

Peraturan Menteri Dalam Negeri Nomor 61 Tahun 2007 tentang Pedoman Teknis Pengelolaan Keuangan Badan Layanan Umum Daerah menjelaskan bahwa Badan Layanan Umum Daerah (BLUD) adalah Satuan Kerja Perangkat Daerah atau Unit Kerja pada Satuan Kerja Perangkat Daerah di lingkungan Pemerintah Daerah yang dibentuk untuk memberikan pelayanan kepada masyarakat berupa penyediaan barang dan/atau jasa yang dijual tanpa mengutamakan pencarian keuntungan, dan dalam melakukan kegiatannya didasarkan pada prinsip efisiensi dan produktivitas. 
BLUD beroperasi selaku perangkat kerja dari Pemerintah Daerah untuk tujuan pemberian layanan umum secara lebih efektif dan efisien. Pemerintah Daerah juga memberikan fleksibilitas kepada Satuan Kerja maupun Unit Kerja BLUD dalam hal pengelolaan keuangannya. Instansi Pemerintah yang telah mengimplementasikan Pola Pengelolaan Keuangan (PPK)-BLUD berkenaan dengan penyediaan barang dan/atau jasa layanan umum adalah Rumah Sakit Umum dan Rumah Sakit Khusus. Namun, pada saat ini tidak hanya Rumah Sakit Umum dan Rumah Sakit Khusus saja yang berpeluang untuk mengimplementasikan PPK-BLUD, puskesmas juga berpeluang setara untuk mencecap asam manisnya status BLUD.

Menteri Koordinator Bidang Kesejahteraan Rakyat, Agung Laksono, mengemukakan bahwa saat ini di Indonesia terdapat sekitar \pm 9.000 puskesmas, 158 diantaranya berstatus BLUD, serta pada tahun 2013 terdapat tambahan 168 puskesmas menjadi BLUD dan 101 dalam proses pengusulan menjadi BLUD (www.jamsosindonesia.com, diakses 25 Agustus 2017). Berdasarkan data tersebut, ternyata sampai saat ini masih terdapat "dualisme" status puskesmas di Indonesia, dimana $\pm 99.96 \%$ puskesmas masih berstatus non-BLUD, tetapi hanya $0.04 \%$ yang telah bersatus BLUD. Oleh karena itu, bermula dari besarnya gap status puskesmas di Indonesia, Agung Laksono selaku Menteri Koordinator Bidang Kesejahteraan Rakyat diberikan mandat oleh Presiden untuk secepatnya mengoordinasikan proses perubahan status puskesmas menjadi BLUD dengan para pejabat terkait lainnya.

Kemudian, menanggapi adanya wacana perubahan predikat puskesmas menjadi BLUD, Pemerintah Daerah di Kabupaten Malang saat ini juga mengupayakan hal serupa. Bupati Malang pasca resmi menjabat sebagai Kepala Daerah meluncurkan Program 100 (Seratus) Hari Kerja. Program pertama Bupati Malang salah satunya mencanangkan mengenai puskesmas BLUD dengan tujuan untuk meningkatkan kualitas pelayanan kesehatan di Kabupaten Malang melalui predikat BLUD. Puskesmas Sumberpucung merupakan salah satu Unit Pelaksana Teknis di Kabupaten Malang yang telah mengimplementasikan PPK-BLUD sejak 1 Januari 2016. Namun, predikat BLUD yang disematkan hanya berupa predikat BLUD Bertahap, yang dituntut mengimplementasikan PPK-BLUD sesuai dengan Peraturan Menteri Dalam Negeri Nomor 61 Tahun 2007. Hal tersebut mampu mendorong pada perubahan organisasi yang dideskripsikan melalui New Institutionalism Theory (NIT). Selanjutnya, pengimplementasian PPK-BLUD adalah upaya Puskesmas Sumberpucung untuk memperoleh legitimasi. Dalam perspektif NIT, upaya menyesuaikan diri sehingga mirip dengan lingkungannya ini dikenal sebagai isomorphism. DiMaggio \& Powell (1983) serta Carruthers (1995) mengungkapkan bahwa terdapat tiga cara yang dapat ditempuh oleh organisasi untuk menjadi mirip (isomorphism) dengan lingkungan kelembagaannya sehingga bisa memperoleh legitimasi atas segala aktivitas organisasi, yakni coercive, mimetic dan normative.

Penelitian ini mengacu pada penelitian terdahulu oleh Susandi, dkk. (2017); Rosnidah, dkk. (2016); Nadilla, dkk. (2016); Syahril (2013); dan Amirya, dkk. (2012). Tentunya, penelitian yang akan dilakukan oleh peneliti berbeda dengan penelitian yang telah dilakukan sebelumnya, karena penelitian ini memfokuskan pada pemaknaan aktor atas perubahan Puskesmas Sumberpucung menjadi BLUD dalam perspektif Teori Institusional serta pemaknaan aktor atas peran akuntansi dalam perubahan Puskesmas Sumberpucung menjadi BLUD.

\section{METODE}

Penelitian ini merupakan penelitian kualitatif dengan menggunakan pendekatan fenomenologi dan paradigma interpretif. Creswell (2015:105) memaparkan bahwa studi fenomenologi mendeskripsikan pemaknaan umum dari sejumlah individu terhadap berbagai pengalaman hidup mereka terkait dengan konsep atau fenomena. Triyuwono (2009:217) memaparkan bahwa paradigma interpretif lebih menekankan pada makna atau interpretasi seseorang terhadap sebuah simbol. Peneliti menggunakan pendekatan fenomenologi dan paradigma interpretif dengan maksud untuk mendalami pemaknaan aktor atas perubahan Puskesmas Sumberpucung menjadi BLUD dalam perspektif Teori Institusional serta peran akuntansi dalam perubahan Puskesmas Sumberpucung menjadi BLUD. Peneliti bertindak selaku alat atau instrumen penelitian dan nonpartisipan atau pengamat sebagai partisipan. 
Penelitian ini bertempat pada salah satu UPT di Kabupaten Malang, yakni "Puskesmas Sumberpucung" yang berlokasi di Jalan Jenderal Sudirman Nomor 2 Sumberpucung, Kabupaten Malang. Data yang dipergunakan oleh peneliti dalam memaparkan temuan penelitiannya adalah data primer dan data sekunder. Data primer diperoleh melalui wawancara semiterstruktur kepada Kepala Puskesmas Sumberpucung; Kepala Tata Usaha; Karyawan Bagian Poli Umum; serta Karyawan Bagian Kepegawaian guna menggali informasi secara gamblang dan detail mengenai perubahan Puskesmas Sumberpucung menjadi BLUD dalam perspektif Teori Institusional. Wawancara juga dilakukan kepada Kepala Puskesmas Sumberpucung; Bendahara Pengeluaran Pembantu; Bendahara Penerimaan Pembantu; Kasir; maupun Apoteker guna menggali informasi secara gamblang dan detail mengenai peran akuntansi dalam perubahan Puskesmas Sumberpucung menjadi BLUD. Data sekunder berasal dari catatan lapangan maupun sumber tertulis. Peneliti menggunakan Miles \& Huberman (1994) sebagaimana dirujuk oleh Martono (2015:11) untuk melakukan analisis data, dimana terdiri dari pengumpulan data; reduksi data; penyajian data; dan penarikan kesimpulan atau verifikasi. Kemudian, untuk pengecekan keabsahan temuan penelitian, peneliti menggunakan triangulasi data dan metode.

\section{HASIL DAN PEMBAHASAN \\ Pemaknaan Aktor atas Perubahan Puskesmas Sumberpucung menjadi BLUD dalam Perspektif Teori Institusional}

a) Coercive Isomorphism: Dominasi Regulasi dan Program 100 Hari Kerja Pemerintah Kabupaten Malang

DiMaggio \& Powell (1983:150) mengungkapkan bahwa coercive isomorphism diakibatkan dari adanya tekanan-tekanan formal maupun informal yang diterima organisasi, tekanan-tekanan itu dapat berasal dari organisasi lainnya dimana organisasi itu bergantung maupun dari harapan kultural di masyarakat sekitar dimana organisasi itu beroperasi. Tekanan-tekanan semacam itu dapat dirasakan sebagai paksaan, sebagai persuasi atau pun sebagai undangan untuk bergabung dalam kolusi. Dalam beberapa keadaan, perubahan organisasi merupakan respons langsung terhadap mandat Pemerintah. Apabila dikaitkan dengan penelitian ini, maka gejala coercive isomorphism yang dialami oleh Puskesmas muncul sebagai bentuk respons langsung dari adanya tuntutan Pemerintah Daerah dan Dinas Kesehatan selaku SKPD, dimana mereka mengharapkan Puskesmas di Kabupaten Malang dapat berpredikat BLUD. Dengan demikian, mau tidak mau puskesmas selaku Unit Kerja pada SKPD harus tunduk dan berupaya untuk merealisasikan harapan dari Pemerintah Daerah dan Dinas Kesehatan. Hal itu mampu mendorong Puskesmas untuk menyesuaikan diri dengan lingkungan sosial, khususnya lingkungan hukum yang menuntut efisiensi, efektivitas, produktivitas, akuntabilitas, dan transparansi dalam hal pelaksanaan program kerjanya. Hal ini sebagaimana dipertegas dalam Peraturan Menteri Dalam Negeri Nomor 61 Tahun 2007.

Lantas, pembahasan tersebut didukung dengan adanya penelitian terdahulu oleh Amirya, dkk. (2012:349) dimana hasil penelitian mengemukakan bahwa pengembangan sistem anggaran dan akuntansi BLU di lingkup UB terjadi karena adanya tuntutan dari Peraturan Pemerintah yang mau tidak mau harus dilaksanakan secara tanggap dan tepat waktu. Hal ini mendorong UB untuk menyesuaikan diri terhadap perubahan lingkungan sosial terutama lingkungan hukum yang dipertegas dengan diberlakukannya Peraturan Pemerintah Nomor 23 Tahun 2005. Tuntutan Peraturan Pemerintah dipandang UB sebagai kewajiban. Dengan kata lain, pengadopsian struktur formal ke dalam organisasi supaya menjadi aturan yang terinstitusionalisasi lebih ditujukan untuk memperoleh legitimasi atas segala aktivitas organisasi. Selanjutnya, deskripsi ini mencerminkan gejala coercive isomorphism.

Apabila dikaitkan dengan penelitian ini, gejala coercive isomorphism lainnya terjadi akibat adanya "Regulasi Pemerintah Daerah", yakni berupa Keputusan Bupati Malang Nomor: 188.45/232/KEP/421.013/ 2015 tentang Unit Pelaksana Teknis Dinas Pusat Kesehatan Masyarakat Sumberpucung pada Dinas Kesehatan Kabupaten Malang untuk Menerapkan Pola Pengelolaan Keuangan Badan Layanan Umum Daerah dengan Status Badan Layanan Umum Daerah Bertahap. Pasca menyandang predikat BLUD Bertahap, unit terkait diharuskan untuk mengimplementasikan PPK-BLUD sesuai dengan Peraturan Menteri Dalam Negeri Nomor 61 Tahun 2007. Dalam hal ini, 
status BLUD Bertahap tidak memberikan fleksibilitas dalam berbagai hal, seperti pengelolaan investasi, pengelolaan utang, pengadaan barang dan/atau jasa, penetapan tarif pelayanan kesehatan, serta rekrutmen tenaga kerja. Pengimplementasian PPK-BLUD sesuai dengan Peraturan Menteri Dalam Negeri Nomor 61 Tahun 2007 lebih ditujukan untuk memenuhi kewajiban puskesmas sebagai Unit Kerja BLUD.

Pembahasan tersebut didukung dengan adanya hasil penelitian terdahulu oleh Astutiningrum, dkk. (2014:600) yang mengungkapkan bahwa penyusunan RBA RSUD dr. Iskak Tulungagung dimulai pada tahun 2009 dengan dibentuknya Tim Penyusun Anggaran dengan didampingi Tim Pendamping Implementasi PPK-BLUD dari BPKP. Pada dasarnya penyusunan RBA pada saat itu ditujukan hanya sebagai pemenuhan kewajiban dalam rangka penyusunan RBA sebagaimana diatur di dalam Peraturan Menteri Dalam Negeri Nomor 61 Tahun 2007, lantaran penetapan RSUD sebagai Satuan Kerja BLUD. Hasil wawancara dengan para informan menyatakan bahwa penyusunan RBA pada saat itu bukan atas pertimbangan manfaat, tetapi hanya sekadar memenuhi kewajiban, lantaran kekhawatiran akan dicabutnya status BLUD oleh Pemerintah Daerah. Lantas, kepatuhan RSUD dr. Iskak Tulungagung dalam rangka pengimplementasian PPK-BLUD sesuai dengan Regulasi dapat dianggap sebagai salah satu upaya untuk memperoleh legitimasi. Hal ini menunjukkan bahwa faktor eksogen berupa gejala coercive isomorphism telah terjadi.

Selanjutnya, penetapan predikat BLUD Bertahap pada puskesmas memicu reaksi dari para informan. Mayoritas berargumen pro dengan status BLUD terlepas dari apakah itu BLUD Bertahap ataupun BLUD Penuh. Mereka menerima perubahan itu dengan sangat antusias. Namun, ada juga yang kontra dengan status BLUD Bertahap, mereka cenderung tak menerima perubahan itu. Wittig (2012:24) mengungkapkan bahwa reaksi karyawan terhadap perubahan organisasi terdiri dari 2 (dua) hal, yakni penerimaan maupun penolakan. Oreg (2006) dalam Wittig (2012:25) mengungkapkan bahwa memungkinkan bagi agen perubahan (Pemerintah Kabupaten Malang dan Dinas Kesehatan) untuk mengidentifikasi penerimaan dan penolakan karyawan. Hal itu amat penting dilakukan lantaran sebagai upaya untuk menyukseskan implementasi perubahan organisasi (puskesmas BLUD dengan predikat Penuh). Penolakan merupakan sikap multidimensi terhadap perubahan organisasi, dimana terdiri dari afektif (perasaan terhadap perubahan organisasi), kognitif (evaluasi mengenai layak dan manfaat dari perubahan organisasi) serta perilaku (niat untuk bertindak melawan perubahan organisasi).

Apabila dikaitkan dengan penelitian ini, maka IC maupun IT tergolong ke dalam aktor yang menerima penetapan predikat BLUD Bertahap. Dalam hal ini, mereka menerima perubahan itu dengan sangat antusias meskipun hanya berpredikat BLUD Bertahap. IC mengutarakan positif (mendukung) dengan status BLUD, sedangkan IT mengutarakan senang dan memang berkeinginan untuk menjadi BLUD. Dengan demikian, dua argumen itu sama-sama menuturkan antusiasme menjadi puskesmas BLUD, yakni dengan mengesampingkan realitas bahwa hanya mencapai predikat BLUD Bertahap. Selanjutnya, IS selaku tim persiapan tergolong ke dalam aktor yang menolak penetapan predikat BLUD Bertahap. Penolakan IS dapat dikaitkan dengan konsep penolakan Oreg, yakni IS merasa kurang puas (afektif) dengan status BLUD Bertahap yang disematkan pada Puskesmas Sumberpucung. IS hanya berkeinginan untuk berstatus BLUD Penuh saja, bukan BLUD Bertahap. IS mengutarakan bahwa dengan status BLUD Bertahap tersebut Puskesmas Sumberpucung tetap tidak dapat berkutik. IS mengistilahkan BLUD Bertahap layaknya "kebebasan terbatas" (kognitif). IS pun mengungkapkan bahwa sebetulnya predikat BLUD Penuh merupakan goal atau tujuan akhir, sehingga para aktor berupaya untuk merealisasikan predikat BLUD Penuh itu (perilaku).

\section{b) Mimetic Isomorphism: Bergaya Ala Swasta}

DiMaggio \& Powell (1983:151) mengungkapkan bahwa tidak semua institutional isomorphism disebabkan oleh adanya paksaan, ketidakpastian yang dihadapi oleh organisasi juga bisa menjadi tekanan yang kuat untuk melakukan perubahan organisasi dengan cara mengimitasi. Ketika teknologi organisasi dipahami dengan buruk, ketika tujuan organisasi ambigu atau ketika lingkungan organisasi menciptakan ketidakpastian secara simbolis, organisasi dapat memodelkan dirinya pada organisasi lain. Kemudian, apabila dikaitkan dengan penelitian ini, maka gejala mimetic 
isomorphism dicerminkan pada upaya yang dilakukan oleh Puskesmas Sumberpucung untuk menjadi mirip (isomorphism) dengan lingkungan kelembagaannya (memodelkan dirinya dengan BLUD). Puskesmas Sumberpucung melakukan perubahan pada struktur organisasinya dalam upaya pengimplementasian PPK-BLUD, dengan mengacu pada Peraturan Menteri Dalam Negeri Nomor 61 Tahun 2007 mengenai Tata Kelola BLUD. Peraturan ini mengharuskan BLUD beroperasi berdasarkan pola tata kelola atau peraturan internal, yang memuat antara lain struktur organisasi, prosedur kerja, pengelompokan fungsi secara logis, serta pengelolaan sumber daya manusia, dimana tata kelola tersebut harus memperhatikan prinsip-prinsip, yakni transparansi, akuntabilitas, responsibilitas, dan independensi.

Gejala mimetic isomorphism lainnya dicerminkan pada upaya mengimitasi praktik organisasi lainnya yang dianggap telah berhasil mengimplementasikan PPK-BLUD, seperti halnya pada Rumah Sakit Umum Daerah (RSUD) X yang notabene telah senior dalam menyandang predikat BLUD Penuh di lingkup Kabupaten Malang. Namun, Puskesmas Sumberpucung dengan predikat BLUD Bertahap pastinya tak bisa sepenuhnya mengimitasi Pola Pengelolaan Keuangan RSUD X, lantaran Puskesmas Sumberpucung hanya diberikan fleksibilitas pada batas-batas tertentu oleh Pemerintah Daerah berkaitan dengan PPK. Dalam hal ini, Puskesmas Sumberpucung hanya mampu mencapai level untuk mengelola, memanfaatkan serta mempertanggungjawabkan keuangannya secara mandiri selayaknya RSUD X.

Selanjutnya, mengenai pengelolaan, pemanfaatan serta pertanggungjawaban keuangan secara mandiri tersebut dikonotasikan sebagai berikut: (a) Pengelolaan: Puskesmas Sumberpucung pasca berpredikat BLUD Bertahap memiliki kendali penuh untuk menyimpan kas dan mengelola rekening Bank (Rekening Kas BLUD di Bank JATIM). Penerimaan BLUD setiap harinya disetorkan seluruhnya ke rekening kas BLUD dan dilaporkan kepada Pejabat Keuangan BLUD. Pencairan dananya pun tidak harus melalui Dinas Kesehatan, tetapi bisa melalui pencairan dana sendiri, dengan ketentuan bahwa pencairan dana hanya dapat dilakukan satu kali saja di akhir bulan; (b) Pemanfaatan: Selepas pencairan dana, dana tersebut dimanfaatkan untuk membiayai berbagai macam pengeluaran pada bulan tersebut yang telah pagu atau sesuai dengan anggaran biaya. IA selaku Bendahara Pengeluaran Pembantu hanya bertugas untuk mengambil uang yang disimpan di Rekening Kas BLUD serta melaporkan dan mempertanggungjawabkan atas penggunaan uang tersebut. Setelah mengambil uang, IA lantas menyerahkan ke Pejabat Pelaksana Teknis Kegiatan (PPTK). PPTK-lah yang bertugas untuk mencatat dan membayar berbagai macam pengeluaran pada bulan tersebut yang telah pagu anggaran biaya; (c) Pertanggungjawaban: Pasca berpredikat BLUD Bertahap, Puskesmas Sumberpucung diharuskan untuk menyusun Laporan Keuangan sesuai dengan SAP kepada Pemerintah Daerah. Laporan Keuangan tersebut berperan sebagai media pelaporan dan pertanggungjawaban atas pengelolaan dan pemanfaatan keuangan secara mandiri (untuk lebih detailnya, pembahasan akan diuraikan pada peran Akuntansi Keuangan).

Lebih lanjut, dengan adanya kendali penuh untuk mengelola, memanfaatkan serta mempertanggungjawabkan keuangannya secara mandiri tersebut, para aktor (IT, IA dan IL) mengistilahkan untuk kemandirian tersebut layaknya "bergaya ala swasta", sebagaimana ungkapan IT.

"Saya senangnya karena saya belajar mandiri, tidak bergantung. Jadi, kayak bergaya kayak swasta begitu lo."

IT pun juga menekankan bahwa hal itu hanyalah pengibaratan saja, bukan berarti status BLUD Bertahap membuatnya menjadi "swasta" layaknya terbebas dari kungkungan Dinas Kesehatan maupun Pemerintah Daerah. Namun, tetap saja Puskesmas Sumberpucung sebagai Unit Pelaksana Teknis Dinas Kesehatan, dimana segala hal mengenai penyusunan dan pelaksanaan rencana program kerja tetap dimonitor oleh Pemerintah Kabupaten Malang melalui Dinas Kesehatan. Hanya saja, status BLUD Bertahap memberikannya tanggung jawab untuk mengelola keuangan secara mandiri, sebagaimana ungkapan IT.

“... tetapi tetap dengan rambu-rambu ada. Kita tidak sama dengan swasta, tetapi gayanya bahwa kita itu sudah seperti kayak swasta ..." 


\section{c) Normative Isomorphism: Keterlibatan Aktor Profesional dalam Rangka Pengimplementasian PPK-BLUD}

DiMaggio \& Powell (1983:152) mengungkapkan bahwa sumber ketiga dari upaya untuk menjadi mirip (isomorphism) dengan lingkungan kelembagaannya dalam perubahan organisasi adalah bersifat normatif serta utamanya berasal dari profesionalisasi. Larson (1977) \& Collins (1979) sebagaimana dirujuk oleh DiMaggio \& Powell (1983:152) menafsirkan bahwa profesionalisasi sebagai upaya kolektif dari anggota organisasi untuk menentukan keadaan dan metode kerja mereka, untuk mengendalikan "the production of producers" serta untuk membangun basis kognitif dan legitimasi atas segala aktivitas organisasi. Selanjutnya, apabila dikaitkan dengan penelitian ini, maka gejala normative isomorphism tampak dari adanya berbagai upaya dari anggota organisasi untuk menentukan keadaan dan metode kerja mereka dalam hal pengimplementasian PPK-BLUD. Dalam hal ini, upaya dilakukan dengan mengikutsertakan peran dari aktor-aktor profesional di luar organisasi demi mempermudah anggota organisasi dalam mengadopsi konsep tertentu berkaitan dengan PPK-BLUD.

Lantas, hal ini dibuktikan, sebelum berpredikat BLUD Bertahap, Tim Persiapan dalam memenuhi segala hal yang dipersyaratkan untuk menerapkan PPK-BLUD (Persyaratan Substantif, Teknis maupun Administratif), didukung dengan adanya keterlibatan aktor-aktor profesional di luar organisasi seperti halnya Perwakilan Badan Pengelola Keuangan dan Aset Daerah (BPKAD) Provinsi, Dinas Kesehatan hingga PTN Kenamaan di Kota Malang (UX) yang telah lebih dulu menyandang label BLU Penuh. Selanjutnya, pasca mencapai predikat BLUD Bertahap, Puskesmas Sumberpucung pun melakukan berbagai upaya perbaikan atau peng-upgrade-an secara berkelanjutan terhadap perubahan teknologi yang ada kini. Wujud dari perubahan teknologi tersebut adalah diterapkannya aplikasi teknologi komputer sebagai salah satu alat bantu dalam proses pengimplementasian PPK-BLUD, terutama untuk Akuntansi BLUD. TI sangat berperan dalam membantu anggota organisasi, terutama bagian keuangan, untuk mempermudah penyelesaian serangkaian tugas melalui bantuan Program Aplikasi Sistem Informasi Manajemen Daerah (SIMDA). Berdasarkan temuan penelitian sebagaimana yang telah dikemukakan pada Bab sebelumnya, peneliti dapat menarik simpulan bahwa Puskesmas Sumberpucung pasca mencapai predikat BLUD Bertahap mengembangkan Program Aplikasi SIMDA Keuangan, sebagaimana ungkapan IA.

"Kita aplikasinya kan itu aplikasinya SIMDA itu kan dari pemerintahnya seperti itu memang. Akhirnya, jadi laporan SAP tadi."

Selanjutnya, Puskesmas Sumberpucung pun mengembangkan Program Aplikasi SIMDA Barang Milik Daerah (BMD) dan Pendapatan, sebagaimana ungkapan IA.

"Ya itu kita mencatat pendapatan, kita itu mencatat pendapatan itu kita tidak per item itu. Kita masukannya per hari. Jadi, aset pun itu juga di-entry di SIMDA pas kita membuat laporan apa tahunan itu tadi."

Program Aplikasi SIMDA Keuangan digunakan untuk pengelolaan keuangan daerah yang berkaitan dengan akuntansi dan pelaporan, dimana meliputi jurnal, buku besar, buku pembantu, dan laporan keuangan berdasarkan pada Standar Akuntansi Pemerintahan (SAP) (laporan realisasi anggaran, laporan arus kas dan neraca). Selanjutnya, Program Aplikasi SIMDA Barang Milik Daerah (BMD) digunakan hanya untuk meng-entry data mengenai penyusutan aset tetap yang benar-benar ada di Puskesmas Sumberpucung berdasarkan laporan penyusutan aset tetap Pemerintah Kabupaten Malang. Sementara, Program Aplikasi SIMDA Pendapatan menghasilkan laporan pertanggungjawaban bendahara penerimaan (SPJ pendapatan - fungsional), buku pendapatan harian, register tanda bukti penerimaan, buku kas umum, surat tanda setoran, dan register Surat Tanda Setoran (STS). 


\section{Pemaknaan Aktor atas Peran Akuntansi dalam Perubahan Puskesmas Sumberpucung Menjadi BLUD}

a) Akuntansi Manajemen: Mengenal Rencana Strategis Bisnis dan RBA Tahunan

Akuntansi manajemen berperan cukup besar dalam rangka mendorong perubahan puskesmas menjadi BLUD, terlebih lagi akuntansi manajemen mendukung terealisasinya PPK-BLUD pasca menyandang predikat BLUD Bertahap demi mencapai predikat BLUD Penuh. Predikat BLUD Penuh merupakan goal atau tujuan akhir yang hendak dicapai, sehingga para aktor bahu-membahu untuk merealisasikan predikat BLUD Penuh tersebut, yakni dengan menyusun rencana strategis bisnis dan anggaran. Hansen \& Mowen (2012:9) memaparkan bahwa akuntansi manajemen dapat disebut sebagai akuntansi internal, dimana berguna untuk mengidentifikasi, mengumpulkan, mengukur, mengklasifikasi, dan melaporkan informasi keuangan maupun non-keuangan yang bermanfaat bagi pengguna internal dalam rangka merencanakan, mengendalikan dan mengambil keputusan. Akuntansi manajemen ditujukan untuk menyediakan informasi bagi pengguna internal (pihak internal puskesmas) untuk membuat keputusan guna mencapai tujuan organisasi.

Selanjutnya, apabila dikaitkan dengan penelitian ini, maka peran akuntansi manajemen direfleksikan sebagai media penyusunan rencana strategis bisnis lima tahunan (pra BLUD) dan Rencana Bisnis Anggaran (RBA) tahunan, yakni mengenai anggaran pendapatan dan biaya (pasca BLUD Bertahap). IS pun selaku Tim Persiapan Rencana Strategis Bisnis dan Laporan Keuangan menuturkan kepada peneliti mengenai urgensi peran akuntansi manajemen pada saat memenuhi persyaratan administratif dalam rangka usulan pengimplementasian PPK-BLUD. Dalam hal ini, persyaratan administratif PPK-BLUD mengharuskan bakal Unit Kerja BLUD memenuhi beberapa dokumen persyaratan administratif diantaranya adalah rencana strategis bisnis, sebagaimana ungkapan IS.

"Penting sekali (sambil tertawa). Karena, dulu em kebetulan saya yang mengerjakan rencana strategis bisnis ya. Itu benar-benar ilmunya ketika kita mengerjakan aduh saya benar-benar belajar, apa ini, apa namanya itu saya lupa, istilah-istilah akuntansi ya itu yang saya enggak mengerti ..."

Peraturan Menteri Dalam Negeri Nomor 61 Tahun 2007 mendefinisikan rencana strategis bisnis sebagai rencana strategis lima tahunan yang mencakup pernyataan visi, misi, program strategis, pengukuran pencapaian kinerja, rencana pencapaian lima tahunan, dan proyeksi keuangan lima tahunan dari SKPD atau Unit Kerja pada SKPD. Rencana strategis bisnis BLUD dipergunakan sebagai dasar penyusunan RBA dan evaluasi kerja. Selanjutnya, terhitung 2 (dua) tahun berpredikat BLUD Bertahap sekaligus berarti Puskesmas Sumberpucung telah berupaya merealisasikan rencana strategis bisnis lima tahunannya. Untuk merealisasikan rencana strategis bisnis lima tahunannya tersebut, SKPD maupun Unit Kerja pada SKPD diharuskan menyusun RBA tahunan, dengan tetap berpatokan pada rencana strategis bisnis lima tahunannya. Peraturan Menteri Dalam Negeri Nomor 61 Tahun 2007 mendefinisikan RBA tahunan sebagai penjabaran lebih lanjut dari program dan kegiatan BLUD dengan berpedoman pada rencana strategis bisnis BLUD. Selanjutnya, penyusunan RBA tahunan harus disusun berdasarkan prinsip anggaran berbasis kinerja (performance based budgeting).

Namun demikian, realitasnya mencerminkan bahwa RBA tahunan yang telah disusun belum menerapkan prinsip anggaran berbasis kinerja (performance based budgeting). Hal tersebut direfleksikan melalui pemikiran aktor (IA) yang masih belum bisa meninggalkan "paradigma lama" mengenai "daya serap anggaran pendapatan dan biaya". IA meyakini apabila SP2B FKTP yang berisi mengenai surat permintaan pengesahan pendapatan maupun belanja dari dana kapitasi Kapitasi Jaminan Kesehatan Nasional (JKN) pada FKTP sekaligus juga surat permintaan pengesahan pendapatan maupun belanja dari dana BLUD (operasional) untuk pemerintah daerah "tidak disahkan" oleh pemerintah daerah, maka Puskesmas Sumberpucung selaku Unit Kerja BLUD dianggap tidak mampu dalam "menyerap anggaran pendapatan dan biaya-nya" dengan saksama, sebagaimana ungkapan IA.

“... Jadi, e (sambil berpikir) kita belanja itu berapa, untuk apa itu ada laporannya setiap bulan ke BPKAD dan itu disahkan oleh pejabat di sana, baru baru itu belanja 
kita sudah diakui, kalau belum disahkan di sana dianggap (sambil berpikir) kita tidak bisa menyerap anggaran yang sudah kita setor ke Bank JATIM tadi."

Selanjutnya, ungkapan IA di atas menyiratkan clue atau petunjuk bahwa sebetulnya tidak hanya Unit Kerja SKPD (puskesmas BLUD) saja yang masih belum bisa meninggalkan "paradigma lama", tetapi pemerintah daerah pun berlaku demikian. Pemerintah daerah masih melihat indikator tingkat keberhasilan kinerja aparatur (puskesmas BLUD) dari pencapaian "daya serap anggaran pendapatan dan biaya-nya”. IA selaku Pejabat Keuangan BLUD mengutarakan bahwa dalam upaya penyusunan RBA tahunan, yakni mengenai anggaran pendapatan dan biaya, dilakukan dengan menggunakan kombinasi top-down dan bottom-up. Dalam hal ini, penyusunan melibatkan semua unit kerja pelaksana anggaran pada puskesmas BLUD (IA mengistilahkan sebagai Tim Perencanaan), seperti halnya Pemimpin dan Pejabat Keuangan BLUD maupun Pengelola Program sebagai aparatur yang mengetahui secara langsung mengenai aktivitas operasional, sehingga akan diperoleh informasi secara akurat mengenai kebutuhan riil di tiap-tiap unit kerja. Keterlibatan semua unit kerja pelaksana anggaran dalam upaya penyusunan RBA tahunan, yakni mengenai anggaran pendapatan dan biaya bisa diistilahkan sebagai partisipasi anggaran atau anggaran partisipasi.

IA pun mengutarakan bahwa Puskesmas Sumberpucung selaku Unit Kerja BLUD telah menyusun anggaran pendapatan dan biaya untuk periode tahun berikutnya. Jadi, dengan kata lain pada periode tahun sebelumnya, dia telah merencanakan dan menetapkan pendapatan "sebesar ini" yang harus tercapai bahkan terlampaui sekalipun selama kurun waktu setahun (anggaran pendapatan). Kemudian, dari pendapatan "sebesar itu" dia pun telah mengalokasikan dan menguraikan macam-macam biaya selama kurun waktu setahun (anggaran biaya). Dengan demikian, biaya-biaya yang harusnya dikeluarkan oleh PPTK pada bulan ini telah sesuai dengan anggaran biaya atau istilah lainnya sudah pagu dengan anggaran biaya, dimana telah direncanakan dan ditetapkan pada periode tahun sebelumnya.

Kemudian, untuk rincian dari anggaran pendapatan Puskesmas Sumberpucung hanya terdiri dari pendapatan dana kapitasi JKN pada FKTP dan pendapatan BLUD (operasional), dimana untuk pendapatan dana kapitasi JKN pada FKTP ditetapkan "sebesar ini" yang harus diperoleh dari pasien yang terdaftar sebagai peserta JKN atau dengan kata lain pasien BPJS kesehatan. Jadi, Puskesmas Sumberpucung nantinya akan melakukan klaim pendapatan kepada BPJS Kesehatan atas pelayanan kesehatan yang telah diberikan kepada pasien tersebut. Selanjutnya, untuk pendapatan BLUD (operasional) ditetapkan "sebesar ini" yang harus diperoleh dari hasil pelayanan kesehatan kepada masyarakat.

IA pun menuturkan bahwa untuk anggaran biaya harus sesuai dengan regulasi pemerintah. Dalam hal ini, pendapatan yang diperoleh bersumber dari pendapatan dana kapitasi JKN pada FKTP dan pendapatan BLUD (operasional), dialokasikan untuk jasa sarana dan jasa pelayanan kesehatan sebagaimana terdapat dalam Surat Keputusan(SK) nomor sekian yang mengatur tentang persentase penggunaan pendapatan untuk jasa sarana dan jasa pelayanan kesehatan. IA pun mengutarakan bahwa pendapatan dana kapitasi JKN pada FKTP dialokasikan sebesar 60\% untuk jasa pelayanan kesehatan serta $40 \%$ untuk jasa sarana, sedangkan pendapatan BLUD (operasional) dialokasikan sebesar $44 \%$ untuk jasa pelayanan kesehatan serta 56\% untuk jasa sarana. Kemudian, jasa pelayanan kesehatan digunakan untuk membayar tenaga kesehatan maupun tenaga non kesehatan yang melakukan pelayanan kesehatan pada FKTP, sedangkan jasa sarana digunakan untuk membayar biaya operasional pelayanan kesehatan, seperti biaya obat, alat kesehatan, bahan medis habis pakai, bahan cetak atau alat tulis kantor, dan lain-lain.

\section{b) Sistem Informasi Akuntansi: Mengenal Pengendalian Internal Persediaan Obat}

Romney \& Steinbart (2015:10) mendefinisikan Sistem Informasi Akuntansi (SIAAccounting Information System) adalah suatu sistem yang mengumpulkan, mencatat, menyimpan dan mengolah data guna menghasilkan informasi bagi pengambil keputusan, atau secara sederhana SIA dapat dikonotasikan sebagai alat penyedia informasi bagi pembuat keputusan. SIA menjalankan tiga fungsi bisnis penting, yakni mengumpulkan dan menyimpan data mengenai aktivitas, sumber daya dan personel organisasi; mengubah data menjadi informasi sehingga manajemen dapat 
merencanakan, mengeksekusi, mengendalikan, dan mengevaluasi aktivitas, sumber daya dan personel organisasi; serta memberikan pengendalian internal yang memadai untuk mengamankan aset dan data organisasi.

Selanjutnya, apabila dikaitkan dengan penelitian ini, maka peran SIA bagi puskesmas BLUD direfleksikan sebagai media pengendalian internal (internal control) atas persediaan obat-obatan guna menghindari tindakan kekeliruan pengambilan obat-obatan oleh tenaga kesehatan, pencurian dan penyalahgunaan atas persediaan obat-obatan oleh oknum-oknum tertentu. Berkenaan dengan hal ini, pengendalian internal termasuk ke dalam salah satu dari tiga fungsi bisnis penting SIA. Romney \& Steinbart (2015:226) mendefinisikan pengendalian internal (internal control) sebagai proses dan prosedur yang dijalankan organisasi untuk mengamankan aset meliputi mencegah atau mendeteksi perolehan, penggunaan atau penempatan aset yang tidak sah; mengelola catatan dengan detail dan baik guna melaporkan aset organisasi secara akurat dan wajar; memberikan informasi yang akurat dan reliabel; menyiapkan laporan keuangan yang sesuai dengan kriteria yang telah ditetapkan; mendorong dan memperbaiki efisiensi operasional; mendorong ketaatan terhadap kebijakan manajerial yang telah ditentukan; serta mematuhi hukum dan regulasi yang berlaku. Pengendalian internal menjalankan tiga fungsi penting, yakni meliputi pengendalian preventif, pengendalian detektif dan pengendalian korektif.

Lebih lanjut, apabila dikaitkan dengan temuan penelitian, upaya pengendalian preventif atas persediaan obat-obatan direfleksikan dengan diadakannya pencatatan dan pelaporan atas penggunaan persediaan obat-obatan pada Bagian Apotek, dimana terdiri dari Laporan Pemakaian dan Lembar Permintaan Obat (LPLPO) harian dan LPLPO bulanan. Menurut Romney \& Steinbart (2015:227), pengendalian preventif berguna untuk mencegah masalah sebelum timbul. IL selaku Apoteker mengemukakan bahwa setiap hari dia menyusun LPLPO harian, yang berisi rekapan atau catatan harian atas penggunaan persediaan obat-obatan berdasarkan resep obat yang masuk ke Bagian Apotek selama sehari. Dalam hal ini, perekapan atau pencatatan harian masih dilakukan secara manual. Selanjutnya, dari LPLPO harian, IL menyusun LPLPO bulanan berupa rekapan atas penggunaan persediaan obat-obatan selama sebulan ke dalam komputer dengan menggunakan Aplikasi Microsoft Excel, sehingga dari LPLPO bulanan tersebut dapat diketahui berapa sisa stock obat-obatan pada bulan itu (kartu stock).

LPLPO harian disusun untuk menyediakan informasi bagi pengguna internal (bagian apotek), sedangkan LPLPO bulanan disusun untuk menyediakan informasi bagi pengguna internal (bagian apotek dan bagian gudang) serta bagi pengguna eksternal (dinas kesehatan). LPLPO bulanan selain ditujukan sebagai pelaporan atas penggunaan persediaan obat-obatan selama sebulan kepada Dinas Kesehatan, tetapi juga ditujukan sebagai permintaan obat-obatan. Jadi, Puskesmas Sumberpucung selama masih menyandang label BLUD Bertahap, dia tidak diberikan fleksibilitas dalam hal pengadaan barang seperti halnya pengadaan obat-obatan, sehingga saat ini dia masih mendapatkan subsidi obat-obatan dari Gudang Farmasi Kabupaten (GFK) yang berada di Dinas Kesehatan Kabupaten Malang, sedangkan untuk pengambilan persediaan obat-obatan di GFK dilakukan hanya 2 (dua) bulan sekali. LPLPO bulanan diserahkan ke Dinas Kesehatan lazimnya dilakukan tiap awal bulan. Kemudian, dengan adanya LPLPO harian maupun LPLPO bulanan, maka akan meningkatkan upaya pengendalian preventif atas persediaan obat-obatan serta menutup peluang oknum-oknum tertentu untuk mencuri dan menyalahgunakan persediaan obat-obatan.

Selanjutnya, apabila dikaitkan dengan temuan penelitian, maka upaya pengendalian preventif lainnya atas persediaan obat-obatan direfleksikan dengan diadakannya pengawasan obatobatan di bagian gudang. IL selaku Pengawas Obat melakukan penandaan dan penataan obat berdasarkan periode kedaluwarsanya. Untuk penataan obat, IL mempergunakan Metode First In First Out (FIFO) dan First Expiry First Out (FEFO). Sementara, untuk penandaan obat dilakukan dengan berdasarkan pada periode kedaluwarsa dan Look Alike Sound Alike (LASA). Penandaan Obat berdasarkan Periode Kedaluwarsa dilakukan dengan menandai pada kemasan obat dengan menggunakan stiker warna-warna tertentu yang menunjukkan periode kedaluwarsa, seperti halnya untuk obat yang kedaluwarsa kurang dari 3 (tiga) bulan maka IL menandainya dengan "warna merah", sedangkan untuk obat yang kedaluwarsa kurang dari 6 (enam) bulan maka IL menandainya 
dengan "warna kuning", penandaan obat berdasarkan periode kedaluwarsa dilakukan dengan tujuan untuk meminimalkan adanya obat-obatan kedaluwarsa di bagian gudang.

Menurut Romney \& Steinbart (2015:227), pengendalian korektif berguna untuk mengidentifikasi dan memperbaiki masalah serta memperbaiki dan memulihkannya dari kesalahan yang dihasilkan. Upaya pengendalian korektif direfleksikan dengan diadakannya pengarsipan terhadap LPLPO harian maupun LPLPO bulanan. Selanjutnya, Menurut Romney \& Steinbart (2015:227), pengendalian detektif berguna untuk menemukan masalah yang tidak terelakkan. Upaya pengendalian detektif direfleksikan dengan diadakannya stock opname. Jadi, dari kartu stock yang didapatkan dari LPLPO bulanan, IL selaku Bagian Gudang melakukan cross check antara kartu stock dengan stock obat-obatan yang berada di bagian gudang atau istilahnya stock opname. Stock Opname dilakukan untuk mengetahui keakuratan catatan dalam pembukuan bagian apotek. Berkenaan dengan hal ini, stock opname hanya dilakukan sebulan sekali, yakni setiap tanggal 25 (dua puluh lima). Selanjutnya, dari stock opname secara nyata dapat terdeskripsikan bahkan terdeteksi sekalipun mengenai pemakaian obat-obatan yang acap kali keluar, sehingga dari hal itulah IL dapat menyusun perencanaan permintaan obat-obatan kepada Dinas Kesehatan dengan "akurat". Kemudian, stock opname pun berfaedah di kala pendeteksian obat-obatan yang hampir ataupun sudah kedaluwarsa.

\section{c) Akuntansi Keuangan: Hanya Menjalankan "SIMDA" Tanpa Memahami SAP dan} Akuntansi Akrual

Akuntansi keuangan berperan cukup besar dalam rangka mendorong perubahan puskesmas menjadi BLUD, terlebih lagi akuntansi keuangan mendukung terealisasinya PPK-BLUD pasca menyandang predikat BLUD Bertahap demi mencapai predikat BLUD Penuh. Peran Akuntansi Kuangan direfleksikan sebagai media pelaporan dan pertanggungjawaban pada pemangku kepentingan (stakeholders) pasca mencapai predikat BLUD Bertahap. Mulyadi (2009:2) mengemukakan akuntansi keuangan ditujukan untuk menyajikan informasi secara kuantitatif mengenai kondisi keuangan di organisasi bagi stakeholders di luar organisasi. Stakeholders yang berkaitan dengan Puskesmas Sumberpucung pasca mencapai predikat BLUD Bertahap adalah Pemerintah Kabupaten Malang dan Dinas Kesehatan.

Akuntansi keuangan sangat berfaedah sebagai media pelaporan dan pertanggungjawaban pada stakeholders atas pengelolaan dan pemanfaatan keuangan secara mandiri, yakni berupa laporan keuangan. Berdasarkan Peraturan Menteri Dalam Negeri Nomor 61 Tahun 2007 memaparkan bahwa BLUD menyelenggarakan akuntansi dan laporan keuangan sesuai dengan standar akuntansi keuangan yang diterbitkan oleh asosiasi profesi akuntansi Indonesia untuk manajemen bisnis yang sehat. Penyelenggaraan akuntansi dan laporan keuangan menggunakan basis akrual baik dalam pengakuan pendapatan, biaya, aset, kewajiban, dan ekuitas dana.

Puskesmas Sumberpucung pasca mencapai predikat BLUD Bertahap untuk akuntansi dan laporan keuangannya sudah sesuai dengan Standar Akuntansi Pemerintahan (SAP). IA selaku Bendahara Pengeluaran Pembantu meyakini apabila Program Aplikasi SIMDA sudah menerapkan "SAP". Kemudian, untuk pemahaman IA mengenai "apa itu SAP?" IA masih belum mengetahui secara pasti, IA hanya sekadar mengetahui apabila Program Aplikasi SIMDA yang diserahkan oleh Pemerintah Kabupaten Malang telah menerapkan SAP tanpa mempunyai pandangan mengenai arti sebetulnya dari SAP, sebagaimana ungkapan IA.

"Pemerintah. SAP. Jadi, ada kita dikasih aplikasi ya itu yang harus kita kerjakan ..."

Jadi, Pemerintah Kabupaten Malang hanya menginstruksikan Puskesmas Sumberpucung sebagai Unit Kerja pada SKPD agar menjalankan Program Aplikasi SIMDA untuk PPK-BLUD nya, sebagaimana ungkapan IA.

"Kalau SAP itu setau saya ya (sambil berpikir), dia itu dari pemda itu menentukan ini lo laporan yang harus kamu kerjakan ..."

Berdasarkan Peraturan Pemerintah Nomor 71 Tahun 2010 tentang Standar Akuntansi Pemerintahan, SAP adalah prinsip-prinsip akuntansi yang diterapkan dalam rangka menyusun dan menyajikan laporan keuangan pemerintah, dimana prinsip akuntansi dan pelaporan keuangan 
pemerintah dimaksudkan sebagai ketentuan yang dipahami dan ditaati oleh pembuat standar dalam menyusun standar; penyelenggara akuntansi dan pelaporan keuangan dalam melakukan kegiatannya; serta pengguna laporan keuangan dalam memahami laporan keuangan yang disajikan.

Tetapi, untuk saat ini akuntansi dan laporan keuangan masih belum menerapkan Standar Akuntansi Keuangan (SAK). IA mengutarakan spekulasinya bahwa selama masih berpredikat BLUD Bertahap, maka Puskesmas Sumberpucung mendapatkan semacam "dispensasi" dari Pemerintah Daerah untuk tidak menerapkan SAK. Tetapi, andaikata dia telah berhasil mencapai predikat BLUD Penuh, maka lain pula ceritanya. Puskesmas Sumberpucung pun pastinya diinstruksikan oleh Pemerintah Daerah supaya tidak sekadar menerapkan SAP, tetapi juga disertai dengan menerapkan SAK untuk PPK-BLUD nya.

Selanjutnya, mengenai basis akuntansi yang digunakan dalam laporan keuangan pemerintah, IA meyakini apabila Program Aplikasi SIMDA sudah menerapkan "basis akrual", tetapi IA tidak mengetahui secara persis mengenai "apa itu basis akrual?" IA hanya sekadar menjalankan Program Aplikasi SIMDA tanpa mengetahui persis arti dan utilitas dari basis akrual, sebagaimana ungkapan IA.

"Sebenarnya di SIMDA itu sudah akrual, cuma gak ngerti aja, yang ngerti yang punya akuntan. Sudah akrual itu. Sudah pakai akrual kok ya SIMDA itu."

Harrison, dkk, (2012:133) mengungkapkan akuntansi akrual (accrual accounting) mencatat dampak dari transaksi bisnis ketika hal tersebut terjadi. Apabila perusahaan melaksanakan suatu jasa, melakukan penjualan atau mengeluarkan beban, maka Akuntan akan mencatat transaksi bisnis tersebut meskipun dia tidak menerima kas atau membayar kas. Peraturan Pemerintah Nomor 71 Tahun 2010 tentang Standar Akuntansi Pemerintahan Pasal 4 mengemukakan bahwa Pemerintah menerapkan SAP berbasis akrual untuk pengakuan pendapatan, biaya, aset, kewajiban, dan ekuitas dana.

Berdasarkan Peraturan Menteri Dalam Negeri Nomor 61 Tahun 2007, SKPD maupun Unit Kerja pada SKPD harus menyusun Laporan Keuangan BLUD. Puskesmas Sumberpucung selaku Unit Kerja pada SKPD dalam rangka pengimplementasian PPK-BLUD telah menyusun laporan keuangan. Dalam hal ini, pasca berpredikat BLUD Bertahap laporan keuangan sangat bervariasi, yakni laporan keuangan harian, bulanan serta tahunan. Laporan keuangan tahunan terdiri dari Laporan Realisasi Anggaran (LRA), Neraca, Laporan Arus Kas, dan Catatan atas Laporan Keuangan (CaLK). Laporan Keuangan Bulanan terdiri dari SPJ Penerimaan, Surat Pengesahan Pendapatan dan Belanja (SP2B) FKTP, serta SPJ Pengeluaran Biaya Operasional dan Biaya Kapitasi. SPJ Penerimaan berisi Laporan Pertanggungjawaban (SPJ Pendapatan - Fungsional) dari Bendahara Penerimaan Pembantu atas pendapatan yang diperoleh (Pendapatan Dana Kapitasi JKN pada FKTP dan Pendapatan BLUD (Operasional)) selama periode sebulan. SP2B FKTP berisi mengenai surat permintaan pengesahan pendapatan maupun belanja dari Dana Kapitasi JKN pada FKTP sekaligus juga surat permintaan pengesahan pendapatan maupun belanja dari Dana BLUD (Operasional) kepada Pemerintah Daerah. SPJ Pengeluaran Biaya Operasional dan Biaya Kapitasi berisi Laporan Pertanggungjawaban dari Bendahara Pengeluaran Pembantu atas Biaya Operasional dan Biaya Kapitasi yang dikeluarkan selama periode sebulan. Laporan Harian berupa STS, dimana Laporan Harian berisi mengenai pendapatan selama sehari yang dirinci per item di dalam STS.

Selanjutnya, tujuan dari penyusunan laporan keuangan adalah sebagai media pertanggungjawaban atas pengelolaan keuangan dan kegiatan pelayanan kesehatannya, sebagaimana ungkapan IA.

"Yo mempertanggungjawabkan, itu adalah bentuk laporan pertanggungjawaban dari selaku unit atau kita Puskesmas ya."

Dalam hal ini, penyusunan laporan keuangan untuk saat ini hanya ditujukan kepada Dinas Kesehatan maupun Pemerintah Daerah. 


\section{SIMPULAN}

Berdasarkan pada pembahasan yang dikemukakan, penelitian ini telah menjawab fokus penelitian, yakni pemaknaan aktor atas perubahan puskesmas menjadi BLUD dalam perspektif Teori Institusional. Dari dimensi coercive isomorphism adalah adanya dominasi Regulasi dan Program 100 Hari Kerja Pemerintah Kabupaten Malang, dari dimensi mimetic isomorphism adalah bergaya ala swasta, serta dari dimensi normative isomorphism tampak dari adanya peran aktor-aktor profesional di luar organisasi dalam hal pengadopsian konsep tertentu berkaitan dengan PPK-BLUD. Sedangkan, pemaknaan aktor atas peran akuntansi dalam perubahan puskesmas menjadi BLUD dari perspektif akuntansi manajemen adalah mengenal Rencana Strategis Bisnis Lima Tahunan dan Rencana Bisnis Anggaran (RBA) Tahunan, dari perspektif Sistem Informasi Akuntansi (SIA) adalah mengenal pengendalian internal atas persediaan obat-obatan, serta dari perspektif akuntansi keuangan adalah hanya sekadar menjalankan SIMDA tanpa memahami SAP dan akuntansi akrual.

Berkenaan dengan hasil penelitian yang telah didapatkan, peneliti mengajukan beberapa saran yang diharapkan dapat digunakan sebagai pertimbangan maupun evaluasi. Sehubungan dengan perubahan status puskesmas menjadi BLUD, maka sangat dibutuhkan peran dan eksistensi dari pakar akuntansi atau tenaga profesional di bidang perakuntansian. Apabila finansial puskesmas tidak mendukung dilakukannya rekrutmen tenaga kerja yang sesuai dengan bidang kemahirannya (akuntan), maka peningkatan kualitas sumber daya manusia yang ada dapat diusahakan, yakni dengan melalui pembinaan dan pelatihan secara intensif dari pakar akuntansi; dan perlu juga dilakukan pemisahan tugas untuk tiap-tiap fungsi dalam organisasi, lantaran temuan penelitian membuktikan masih ada karyawan yang memegang tanggung jawab pekerjaan lebih dari satu, sehingga hal tersebut mampu memicu ketidak-optimalan dalam pekerjaan.

\section{DAFTAR RUJUKAN}

Amirya, M., Djamhuri, A., \& Ludigdo, U. 2012a. Pengembangan Sistem Anggaran dan Akuntansi Badan Layanan Umum Universitas Brawijaya: Perspektif Institusionalis. Jurnal Akuntansi Multiparadigma, 3(3), 343- 356. Dari http://jamal.ub.ac.id/index.php/jamal/article/view File/193/194.

Amirya, M., Djamhuri, A., \& Ludigdo, U. 2012b. Pengembangan Sistem Anggaran dan Akuntansi Badan Layanan Umum Universitas Brawijaya: Sebuah Studi Interpretatif. Simposium Nasional Akuntansi XV Banjarmasin 2012. Dari http://sna.akuntansi.unikal.ac.id/makalah/ 060-ASPIA-01.pdf.

Astutiningrum., Djamhuri, A., \& Prihatiningtias, Y. W. 2014. New Institutional Theory: Implementasi Anggaran Berbasis Kinerja Menuju Organisasi yang Kompetitif dan Berorientasi Pasar. Jurnal Review Akuntansi dan Keuangan, 4(2), 595- 606. Dari http://ejournal.umm.ac.id/index.php/ jrak/article/view/4944.

Carruthers, Bruce G. 2012. Institutional Dynamics: When is Change "Real Change"?. Working Paper Series, 12-004. Dari http://buffett.northwestern.edu/documents/working-papers/ CHSS-12-004-Carruthers.pdf.

Creswell, John W. 2015. Penelitian Kualitatif \& Desain Riset: Memilih diantara Lima Pendekatan, Edisi 3 (Saifuddin Zuhri Qudsy, Ed). Terjemahan Ahmad Lintang Lazuardi. Yogyakarta: Pustaka Pelajar. 2013.

DiMaggio, P. J. \& Powell, W. W. 1983. The Iron Cage Revisited: Institutional Isomorphism and Collective Rationality in Organizational Fields. American Sociological Review, 48(2), 147160. Dari http://www.ics.uci.edu/ corps/phaseii/DiMaggioPowell-IronCageRevisitedASR.pdf.

Hansen, D. R. \& Mowen, M. M. 2012. Akuntansi Manajerial, Edisi 8: Managerial Accounting, $8^{\text {th }}$ Edition (Lulu Alfiah, Ed). Terjemahan Deny Arnos Kwary. Jakarta: Salemba Empat. 2007.

Harrison, W. T., Horngren, C. T., Thomas, C. W., \& Suwardy, T. 2012. Akuntansi Keuangan, Edisi 8: Financial Accounting, $8^{\text {th }}$ Edition (Suryadi Saat, Ed). Terjemahan Gina Gania. Jakarta: Penerbit Erlangga. 2010.

Martono, Nanang. 2015. Metode Penelitian Sosial: Konsep-Konsep Kunci. Jakarta: Rajawali Pers. 
Mulyadi. 2009. Akuntansi Biaya, Edisi 5. Yogyakarta: UPP STIM YKPN.

Nadilla, T., Basri, H., \& Fahlevi, H. 2016. Identifikasi Permasalahan Penerapan Pola Pengelolaan Keuangan Badan Layanan Umum Daerah (PPK-BLUD): Studi Kasus pada Rumah Sakit Permata dan Rumah Sakit Berlian. Jurnal Magister Akuntansi Pascasarjana Universitas Syiah Kuala, 5(2), 89- 99. Dari www.jurnal.unsyiah.ac.id/JAA/article/view/4513.

Peraturan Menteri Dalam Negeri Nomor 61 Tahun 2007 Tentang Pedoman Teknis Pengelolaan Keuangan Badan Layanan Umum Daerah. Kementerian Dalam Negeri. (Online), (http://www.kemendagri.go.id), diakses 25 Agustus 2017.

Peraturan Pemerintah Nomor 23 Tahun 2005 Tentang Pengelolaan Keuangan Badan Layanan Umum. Direktorat Jenderal Perimbangan Keuangan: Kementerian Keuangan. (Online), (http://www.djpk.depkeu.go.id), diakses 25 Agustus 2017.

Peraturan Pemerintah Nomor 71 Tahun 2010 Tentang Standar Akuntansi Pemerintahan. Direktorat Jenderal Perimbangan Keuangan: Kementerian Keuangan. (Online), (http://www.djpk.depkeu.go.id), diakses 25 Agustus 2017.

Romney, M. B. \& Steinbart, P. J. 2015. Sistem Informasi Akuntansi, Edisi 13: Accounting Information Systems, $13^{\text {th }}$ Edition (Muhammad Masykur \& Bambang Hernalyk, Eds). Terjemahan Kikin Sakinah Nur Safira \& Novita Puspasari. Jakarta: Salemba Empat.

Rosnidah, I., Juwenah. \& Astuti, A. D. 2016. Identifikasi Eksisting Sistem Akuntansi Badan Layanan Umum Daerah pada Rumah Sakit Umum Daerah Kabupaten Cirebon. Jurnal Riset Akuntansi dan Keuangan, 4(2), 993- 1004. Dari http://ejournal.upi.edu/ index.php/JRAK/article/view/4033.

Susandi, N. T., Budiartha, K., \& Suprasto, H. B. 2017. Kinerja Keuangan dan Efisiensi Proses Internal Sebelum dan Sesudah Penerapan PPK-BLUD pada RSUD Kabupaten Klungkung. E-Jurnal Ekonomi dan Bisnis Universitas Udayana, 6(4), 1701- 1730. Dari http://ojs.unud.ac.id/index. php/EEB/article/view/27076/18198.

Syahril. 2013. Pola Pengelolaan Keuangan Badan Layanan Umum Daerah (PPK-BLUD) pada RSUD Dr. H. Moh. Anwar Sumenep. Jurnal "Performance" Bisnis dan Akuntansi, 3(1), 31 50. Dari https://ejournal.wiraraja.ac.id /index.php/FEB/article/download/113/84.

Triyuwono, Iwan. 2009. Perspektif, Metodologi dan Teori Akuntansi Syariah. Jakarta: Rajawali Pers. Wittig, Cynthia. (2012). Employees' Reactions to Organizational Change. OD Practitioner, 44(2), 23-28. Dari http://c.ymcdn.com/sites/www.odnetwork.org. 